\title{
PROFILE OF ANEMIA FROM JANUARY TO DECEMBER 2010 AT PROF. Dr. R. D. KANDOU HOSPITAL MANADO
}

\author{
Edwin Jim \\ Harlinda Haroen \\ Linda W. A. Rotty \\ Department of Internal Medicine Sam Ratulangi University \\ Prof. Dr. R. D. Kandou Hospital Manado \\ Email: edwinjim@yahoo.com
}

\begin{abstract}
Abstrak: Anemia merupakan salah satu masalah kesehatan masyarakat yang paling tersebar, terutama di negara berkembang, dengan konsekuensi ekonomi, sosial, kesehatan, dan kesejahteraan yang penting. Anemia dapat disebabkan oleh penyebab terkait nutrisi, keganasan, penyakit infeksi/inflamasi dan juga kehilangan darah. Studi ini merupakan studi deskriptif retrospektif pada pasien rawat inap dengan anemia sejak Januari-Desember 2010 di ruang perawatan Penyakit Dalam RSUP. Prof. Dr. R.D. Kandou Manado. Diagnosis ditegakkan berdasarkan kriteria WHO untuk hemoglobin $(\mathrm{Hb})(<13 \mathrm{~g} \%$ pada laki-laki dan < $12 \mathrm{~g} \%$ pada perempuan yang tidak hamil). Data dikelompokkan berdasarkan gender, usia, dan penyakit terkait. Pasien rawat inap selama Januari - Desember 2010 sebanyak 1.457 laki-laki dan 1.142 perempuan. Anemia ditemukan sebanyak 251 kasus $(17,22 \%)$ pada laki-laki dan 205 kasus (17,95\%) pada perempuan. Pada kedua kelompok, anemia tersering pada usia $>60$ tahun (pada laki-laki 40,63\%, perempuan 43,41\%). Jenis anemia sedang (Hb 6-10 g\%) yang tersering ditemukan (pada laki-laki 57,76\%, perempuan 58,04\%). Penyakit ginjal kronik merupakan penyakit yang tersering ditemukan baik pada pasien anemia laki-laki $(34,26 \%)$ maupun perempuan $(49,75 \%)$. Simpulan: kejadian anemia pada kedua kelompok gender hampir sama banyak, dan yang paling sering ditemukan ialah anemia sedang pada usia $>60$ tahun, dengan penyerta tersering penyakit ginjal kronik.
\end{abstract}

Kata kunci: anemia, hemoglobin, penyakit ginjal kronik.

\begin{abstract}
Anemia is one of the most widespread public health problems, especially in developing countries, and has important health, welfare, social, and economic consequences. Anemia can result from nutrition-related causes, malignancy, inflammatory/infectious diseases, as well as from blood loss. This was a retrospective descriptive study of anemic inpatients from January to December 2010 at the Internal Medicine ward of Prof. Dr. R. D. Kandou Hospital Manado. Diagnosis was based on WHO criteria for hemoglobin (< $13 \mathrm{~g} \%$ for males, $<12 \mathrm{~g} \%$ for non-pregnant females). Data was divided based on gender, age, and related-diseases. There were 1,457 male and 1,142 female in-patients. Anemia was found in 251 cases $(17.22 \%)$ in male in-patients, and 205 cases $(17.95 \%)$ in female in-patients. In both groups, the most frequent cases were found at age > 60 years. Moderate anemia ( $\mathrm{Hb} 6-10 \mathrm{~g} \%)$ was the most frequent anemia (males 57.76\%, females 58.04\%). Chronic kidney diseases were the most related diseases found in both groups. Conclusion: the occurrences of anemia in both genders were nearly the same. Besides that, the most frequent cases in both genders were moderate anemia at age $>60$ years, and the most common related disease was chronic kidney disease.
\end{abstract}

Keywords: anemia, hemoglobin, chronic kidney disease 
Anemia is one of the most widespread public health problems, especially in developing countries, and has important health, welfare, social, and economic consequences. These include impaired cognitive development, reduced physical work capacity, and in severe cases increased risks of mortality. There is also evidence that anemia may result in reduced growth and increased morbidity. As a matter of fact, anemia is not a disease entity, but it represents assorted symptoms of underlying diseases. $^{1}$

It was estimated that more than $30 \%$ of earthlings, or 1.5 milliard cases, were suffering from anemia; mostly living in tropical regions. In facing the magnitude of this problem, greater efforts and implemented programs are needed to prevent and control anemia. ${ }^{2}$

Anemia is a reduction of hemoglobin, erythrocyte, or hematocrit. Normally, the number of erythrocytes shows a balance between production and destruction or loss of erythrocytes. ${ }^{3}$ According to the pathophysiological aspect, anemia is classified as a degradation of production due to loss of erythrocytes. ${ }^{4}$

\section{MATERIALS AND METHOD}

This was a retrospective descriptive study in anemic in-patients from January until December 2010 at the Internal Medicine ward, Prof. Dr. R. D. Kandou Hospital Manado. Diagnosis was based on WHO criteria: hemoglobin $(\mathrm{Hb})<13 \mathrm{~g} \%$ for males and <12 $\mathrm{g} \%$ for non-pregnant females. Data was divided based on gender, age, and related-diseases.

\section{RESULT}

There were 1,457 male and $1,142 \mathrm{fe}$ male in-patients from January-December 2010. Anemia was found in 251 cases $(17.22 \%)$ in males and 205 cases $(17.95 \%)$ in females. In both groups, the most frequent cases were found in age $>60$ years $(40.63 \%$ for males and $43.41 \%$ for females). Moderate anemia ( $\mathrm{Hb} 6-10 \mathrm{~g} \%)$ was the most frequent found in males $(57.76 \%)$ and females $(58.04 \%)$. Chronic kidney diseases were the most related diseases found in males (34.26\%) and females $(49.75 \%)$.

Pursuant to age, males of $>60$ years were 102 cases $(40.63 \%)$ out of 251 males with anemia, or $7.0 \%$ from all male inpatients; ages 50-59 years were 62 cases (24.70\%); ages 40-49 were 36 cases (14.34\%); ages $30-39$ were 32 cases $(12.74 \%)$; ages $20-29$ were 11 cases (4.38\%); and ages $13-19$ were 8 cases $(3.18 \%)$. Females of $>60$ years were 89 cases $(43.41 \%)$ out of 205 females with anemia, or $7.79 \%$ from all female inpatients; ages 50-59 were 46 cases (22.43\%); ages 40-49 were 29 cases (14.14\%); ages $30-39$ were 13 cases (6.34\%); ages 20-29 were 20 cases (9.75\%); and ages $13-19$ were 8 cases $(3.18 \%)$.

From all anemic cases, patients of $>60$ years were 191 cases $(44.88 \%)$ out of all anemic patients, or $7.34 \%$ from all patients; 102 male cases were $(22.36 \%)$ and 89 female were cases (19.51\%); ages 50-59 were 108 cases $(23.68 \%)$; ages $40-49$ were 65 cases (14.25\%); ages 30-39 were 45 cases $(9.86 \%)$; ages $20-29$ were 31 cases (6.79\%); and ages 13-19 were 16 cases $(3.50 \%)$ (Table 1).

Table 1. Age distribution of anemic in-patients

\begin{tabular}{llll}
\hline Age (year) & Male & Female & Total \\
\hline$\geq 60$ & 102 & 89 & 191 \\
$50-59$ & 62 & 46 & 108 \\
$40-49$ & 36 & 29 & 65 \\
$30-39$ & 32 & 13 & 45 \\
$20-29$ & 11 & 20 & 31 \\
$13-19$ & 8 & 8 & 16 \\
\hline Total & 251 & 205 & 456 \\
\hline
\end{tabular}

Pursuant to $\mathrm{Hb}$ values, male patients with $\mathrm{Hb} \geq 10 \mathrm{~g} \%$ were 71 cases $(28.28 \%)$ out of 251 males with anemia; Hb values 6$9.9 \mathrm{~g} \%$ were 145 cases $(57.76 \%$ ); and $\mathrm{Hb}$ values $\leq 5,9 \mathrm{~g} \%$ were 35 cases $(13.94 \%)$. Female patients with $\mathrm{Hb} \geq 10 \mathrm{~g} \%$ were 62 
cases $(30.24 \%)$ out of 205 females with anemia; $\mathrm{Hb}$ values 6-9.9 $\mathrm{g} \%$ were 119 cases (58.04\%); and $\mathrm{Hb}$ values $\leq 5,9 \mathrm{~g} \%$ were 24 cases $(11.70 \%)$.

Of all anemia cases, assessed $\mathrm{Hb}$ values $\geq 10 \mathrm{~g} \%$ were 133 cases $(21.16 \%)$; values of $\mathrm{Hb} 6-9,9 \mathrm{~g} \%$ were 264 cases ( $57.89 \%)$; and values of $\mathrm{Hb} \leq 5.9 \mathrm{~g} \%$ were 59 cases $(12.93 \%)$ (Table 2$)$.

Table 2. Distribution of $\mathrm{Hb}$ values of anemic patients

\begin{tabular}{llll}
\hline $\begin{array}{l}\text { Hemoglobin } \\
\text { (g\%) }\end{array}$ & Male & Female & Total \\
\hline $\begin{array}{l}\text { 10 } \\
\text { (male }<13 ;\end{array}$ & 71 & 62 & 133 \\
female $<12)$ & & & \\
$9-9,9$ & 35 & 30 & 65 \\
$8-8,9$ & 38 & 32 & 70 \\
$7-7,9$ & 35 & 31 & 66 \\
$6-6,9$ & 37 & 26 & 63 \\
$5-5,9$ & 15 & 7 & 22 \\
$\leq 4,9$ & 20 & 17 & 37 \\
\hline Total & 251 & 205 & 456 \\
\hline
\end{tabular}

Pursuant to kinds of related diseases, among male in-patients there were 86 cases $(34.26 \%)$ with chronic kidney diseases (CKD) out of 251 males with anemia, 51 cases $(20.31 \%)$ of tuberculosis, 44 cases $(17.52 \%)$ of gastrointestinal bleeding, 21 cases $(8.36 \%)$ of malignancy, 18 cases $(7.17 \%)$ of malaria, 7 cases $(2.78 \%)$ of aplastic anemia, 7 cases $(2.78 \%)$ of human immunodeficiency virus (HIV) (+), 1 case $(0.39 \%)$ of hemolytic anemia, 1 case $(0.39 \%)$ of hemophilia, and 15 cases $(5.97 \%)$ of other diseases.

Among female in-patients there were 102 cases $(49.75 \%)$ of CKD out of 205 females with anemia, 31 cases $(15.12 \%)$ of tuberculosis, 19 cases $(9.26 \%)$ of gastrointestinal bleeding, 15 cases $(7.31 \%)$ of malignancy, 17 cases $(8.29 \%)$ of malaria, 4 cases $(1,95 \%)$ of aplastic anemia, 2 cases $(0.97 \%)$ of HIV (+), 2 cases $(0.97 \%)$ of hemolytic anemia, 1 case $(0.48 \%)$ of hemophilia, and 12 cases $(8.84 \%)$ of other diseases (Table 3 ).
Table 3. Related-disease distribution in anemic in-patients

\begin{tabular}{llll}
\hline Related-diseases & Male & Female & Total \\
\hline CKD & 86 & 102 & 188 \\
TBC & 51 & 31 & 82 \\
GIT bleeding & 44 & 19 & 63 \\
Malignancy & 21 & 15 & 36 \\
Malaria & 18 & 17 & 35 \\
Aplastic anemia & 7 & 4 & 11 \\
HIV & 7 & 2 & 9 \\
Hemolytic & 1 & 2 & 3 \\
anemia & & & \\
Hemophilia & 1 & 1 & 2 \\
Cirrhosis hepatis & 7 & 6 & 13 \\
CHF & 6 & 3 & 9 \\
DHF & 2 & 3 & 5 \\
\hline Total & 251 & 205 & 456 \\
\hline
\end{tabular}

\section{DISCUSSION}

In this research, anemia was found in $17.22 \%$ of male in-patients and in $17.95 \%$ female in-patients. De Maeyer et al conducted a research about the prevalence of anemia in the world in 1985, as shown in Table 4. ${ }^{1}$ Husaini et $\mathrm{al}^{1}$ suggested a prevalence of anemia for Indonesia in 1989, as follows: adult males $20-30 \%$ and adult non-pregnant females 30-40\%. In Medan, Siregar $(2002)^{5}$ found that anemia in males was $39.13 \%$ out of all male inpatients and in females $38.60 \%$ out of all female in-patients.

Table 4. Prevalence of anemia in the world. ${ }^{1}$

\begin{tabular}{lcc}
\hline Location & Adult males & $\begin{array}{c}\text { Adult non- } \\
\text { pregnant } \\
\text { females }\end{array}$ \\
\hline $\begin{array}{l}\text { Developed } \\
\text { country }\end{array}$ & $3 \%$ & $14 \%$ \\
$\begin{array}{l}\text { Developing } \\
\text { country }\end{array}$ & $26 \%$ & $59 \%$ \\
World & $18 \%$ & $51 \%$ \\
\hline
\end{tabular}

In both groups, anemia was mostly found at the age group of $>60$ years old, consisting of $40.63 \%$ of male in-patients or $7.34 \%$ of all male in-patients; and $43.41 \%$ of female in-patients or $7.79 \%$ of all female in-patients. 
Data of The National Health Nu-trition Examination and Survey (NHANES) from 1988-1994 showed that anemia was found in about $10 \%$ of geriatric patients, which doubled following each decade after 65 years old. ${ }^{6}$ In the United States, Guralnik et al (2004) found that at the age of $>65$ years old $11 \%$ of males and $10.2 \%$ of females suffered from anemia, and the prevalence of anemia increased incrementally with the accretion of age. ${ }^{7}$ Siregar found that anemia most frequently occured in males $>60$ years (27.72\% of male in-patients) and at ages $51-60$ in females $(26.10 \%$ of female inpatients). ${ }^{5}$ A research conducted by Ble et al found that the pre-valence of anemia in a society $>65$ years old was $12 \%$ (11.5\% of males and $12.5 \%$ of females). ${ }^{8}$

We found that moderate anemia in males (Hb 6-9.9 g \%) was the most frequent. Its prevalence was $57.76 \%$ in anemic male in-patients, or $31.78 \%$ of all anemic in-patients; and $58.04 \%$ in anemic female patients, or $24.1 \%$ of all anemic inpatients. On the other hand, Siregar found mild anemia as the most frequent case in males $(53.47 \%)$ and females $(44.17 \%){ }^{5}$

\section{CONCLUSION}

The occurrences of anemia in both genders were nearly the same. Besides that, the most frequent cases in both genders were moderate anemia at age $>60$ years, and the most common related disease was chronic kidney disease.

\section{REFERENCES}

1. Bakta IM. Pendekatan terhadap pasien anemia. In: Sudoyo AW, Setiyohadi B, Alwi I, Simadibrata M, Setiati S, editors. Buku Ajar Ilmu Penyakit Dalam (Edisi Keempat). Jakarta: Departemen Ilmu Penyakit Dalam FKUI, 2006; p.632-5.

2. Nestel P, Davidson L. Anemia, iron deficiency, and iron deficiency anemia. Washington: INACG, 2002.

3. Frenkel EP. Approach to the patient with anemia. In: Porter RS, Beers MH, Jones TV, Kaplan JL, Berkwits M (editors). The Merck Manual of Diagnosis and Therapy. New York: Merck Research Laboratories, 2006; 1031-6.

4. Linker CA. Blood. In: McPhee SJ, Papadakis MA, Tierney LM, editors. Current Medical Diagnosis and Treatment (Forty-sixth Edition). New York: McGraw Hill Medical, 2007; p.493-510.

5. Siregar A. Gambaran pasien anemia yang dirawat di bagian penyakit dalam di RS. H. Adam Malik Medan tahun 2002. Manado: KOPAPDI XII, 2003.

6. Lipschitz D. Medical and functional consequences of anemia in the elderly. J Am Geriatr Soc 2003;51(3 suppl):510-513.

7. Resnick BM, Tangalos EG, Beier MT. Managing anemia in chronic kidney disease patients in long-term care. Monthly Prescribing Reference 2007; A supplement to MPR long-term care edition: s3-s10.

8. Ble A, Fink JC, Woodman RC, Klausner MA, Windham BW, Guralnik JM, et al. Renal function, erythropoietin, and anemia of older persons: the InCHIANTI Study. Arch Intern Med. 2005;165(19):2222-7. 